\title{
Does OFDI Promote High-Quality Development of Enterprises? Evidence from China
}

\author{
Cheng Peng, Xinyuan Jia, Ying Tang \\ Sichuan International Studies University, Chongqing, China \\ Email: de2rjxy@163.com
}

How to cite this paper: Peng, C., Jia, X. Y., \& Tang, Y. (2022). Does OFDI Promote High-Quality Development of Enterprises? Evidence from China. American Journal of Industrial and Business Management, 12, 153-179.

https://doi.org/10.4236/ajibm.2022.122011

Received: January 17, 2022

Accepted: February 22, 2022

Published: February 25, 2022

Copyright $\odot 2022$ by author(s) and Scientific Research Publishing Inc. This work is licensed under the Creative Commons Attribution International License (CC BY 4.0).

http://creativecommons.org/licenses/by/4.0/

\begin{abstract}
Whether foreign direct investment can promote enterprise productivity and high-quality development has not yet reached a consensus in academic circles. By using the samples of A-share listed companies in China from 20082019, this paper adopts Propensity Score Matching (PSM)-Multi-temporal Difference-in-Differences (DID) to examine empirically whether corporate OFDI contributes to the high-quality development of enterprises from the perspective of total factor productivity. The study finds that OFDI significantly improves the total factor productivity of enterprises. It has more effect on state-owned enterprises than on private enterprises, and more effect on enterprises in western regions than on those in eastern and central regions. However, the promotion effect is not present in non-central policy-supported manufacturing enterprises. Technological innovation, exploratory innovation, and exploitative innovation mediate the relationship between OFDI and enterprise high-quality development. This paper provides empirical evidence for how to better promote enterprise innovation strategy and high-quality development under the "dual circulation" development pattern.
\end{abstract}

\section{Keywords}

OFDI, High-Quality Development, Technological Innovation, Total Factor Productivity

\section{Introduction}

The report of the 19th National Congress of the Communist Party of China pointed out that China's economy has changed from the stage of high-speed growth to the stage of high-quality development, thus guiding enterprises from simple expansion to connotative high-quality development. The micro foundation of high-quality economic development is the high-quality development of 
enterprises, which means enterprise growth comes more from total factor productivity, that is to say, the essence and the core of high-quality development of the enterprise are higher total factor productivity (Guo \& Sun, 2021). Therefore, it is particularly important to strive to improve the total factor productivity of enterprises, to inject micro power into the high-quality economic development. Based on this view, Wu and Tong (2016) studied how enterprises can improve total factor productivity under the circumstances of resource constraints and the "new normal" of economic development, and argued that the vitality and efficiency of China's economy and Chinese enterprises should now be based on technological progress. Their argument has led scholars to consider which factors would affect the total factor productivity of enterprises so as to map out an applicable path that can positively promote total factor productivity and highquality development of enterprises.

This paper discusses the intrinsic correlation between OFDI and total factor productivity of enterprises by using a quasi-natural experiment method with a sample of A-share listed companies from 2008 to 2019. Through the analysis, we obtain the effect of OFDI on firm productivity and analyze the mechanisms related to the impact of OFDI on firm productivity from the perspective of technological innovation and heterogeneous innovation. It provides empirical evidence for high-quality OFDI and innovation strategy optimization of firms, which contributes to the high-quality development of firms and the overall economy.

\section{Literature Review}

The available literature suggests that scholars hold that the factors affecting the total factor productivity of enterprises mainly come from internal and external sources. Internal factors mainly include financing constraints (Wang \& Zhang, 2018), technological innovation (Bruno, Ivan, \& Stéphane, 2016), governance structure (Wang, Yue, \& Zhang, 2019), import and export behavior (Luo \& Zhang, 2020) and outward investment (Jiang \& Jiang, 2014). While external factors mainly include the institutional environment (Benjamin, René, \& Wang, 2020), infrastructure (Bronzini \& Piselli, 2009), etc. Thus, it can be seen that Outward Foreign Direct Investment (OFDI) is an important external force affecting the total factor productivity of enterprises.

The macro-level research results are richer in terms of the mechanism of the effect of OFDI on productivity. Most scholars believe that OFDI can boost productivity levels mainly because OFDI can generate reverse technology spillover effects, which can significantly improve the comprehensive innovation capacity (Mao \& Xu, 2014) and regional innovation efficiency (Li, Pang, \& Zhang, 2019). However, testing with the GMM method, Yin and Zhang (2016) found that nationally there is no significant reverse technology spillover effect of OFDI or no evidence showing that OFDI hinders productivity growth. Compared with the rich research results at the macro level, the literature on the impact of OFDI 
on total factor productivity of enterprises at the micro-level is relatively lacking, and a few of them also take industrial enterprises as their samples. The reason for this is that it is relatively easy to obtain the data needed to measure total factor productivity at the macro level, while the replacement of indicators such as intermediate inputs and industrial value-added by listed companies in measuring total factor productivity will have an impact on the accuracy of productivity calculation.

In summary, the possible contributions of this paper are 1) to sort out the mechanism of the effect of OFDI on total factor productivity of enterprises; 2) to clarify whether OFDI promotes enterprise productivity in the new era; 3 ) to innovatively place OFDI, heterogeneous innovation, and enterprise productivity in the same framework for exploration. This article is organized as follows: Part 1 is an introduction; Part 2 is a literature review; Part 3 conducts theoretical analysis and proposes hypotheses; Part 4 is a research design; Part 5 is an analysis of the effect of OFDI on promoting high-quality enterprise development; Part 6 is a mechanism analysis; Part 7 is a robustness test; Part 8 concludes the whole article and provides countermeasure suggestions.

\section{Theories and Research Hypothesis}

\subsection{OFDI and Total Factor Productivity}

According to the international investment theory, foreign direct investment enterprises may obtain faster productivity improvement than enterprises that only produce and sell locally because of various mechanisms. Firstly, the mechanism of personnel mobility. In an open economic environment, as the international cooperation and exchanges between enterprises are becoming frequent, there is a large number of personnel mobility with enterprises' international investment activities, which generates new knowledge spillovers. And through internal training, the spillover effect will be further expanded, helping improve the parent company's technological R\&D capability and knowledge absorption capacity (Song \& Wu, 2016), which eventually improves the productivity of enterprises. In addition, in order to offset the fixed costs and sunk costs of OFDI, enterprises may streamline the unnecessary human resources of the parent company and introduce more high-skilled and intelligent talents, which will also promote the productivity of enterprises. Secondly, the headquarters service mechanism. The parent company needs to supervise and coordinate overseas subsidiaries, and at the same time control the geographically-dispersed production activities (Xiao \& Liu, 2014), i.e., providing "headquarters services" such as product development, international marketing, supply chain management, etc., which enhances the productivity of enterprises. Thirdly, resource allocation mechanism. Through foreign investment, enterprises can allocate relatively inefficient production capacity in the home country to more efficient countries or regions and allocate domestic resources to more efficient production processes and stages (Bernard, Jensen, \& Schott, 2006), which eventually leads to higher production efficiency 
in the home country. Fourthly, technology feedback mechanism. Foreign direct investment is an important channel for cross-border dissemination of knowledge and technology (Aitken \& Harrison, 1994), in which enterprises can absorb the advanced technology and techniques of developed countries and form a late-developing advantage to improve enterprise productivity through "learning by doing". Fifthly, the international competition effect. Enterprises "going global" will inevitably join the fierce competition in overseas markets (Ming, Yan, \& Xian, 2019), and will face more stringent international standards or consumers with higher requirements, which will urge enterprises to pay more attention to the quality of products and services, and encourage them to upgrade technology and optimize management practices (Javorcik, 2004), thus contributing to enterprise productivity. Finally, the agglomeration spillover mechanism. MNCs can form strategic alliances with technologically superior enterprises in the host country, participate in R\&D innovation closely, obtain technology spillovers more efficiently and share the results of joint $R \& D$ (Cheng, 2011), and generate international $R \& D$ spillovers to the parent company through the $R \& D$ results return mechanism (Song \& Wu, 2016), which promotes the improvement of the parent company's technology and productivity. Therefore, this paper proposes the following hypothesis.

$\mathrm{H}_{1}$ : OFDI can significantly improve the total factor productivity of enterprises and promote their high-quality development.

\subsection{OFDI, Technological Innovation, and Total Factor Productivity}

The above analysis shows that OFDI acts on enterprise productivity through various mechanisms, many of which bring about technological innovation and technological progress to enterprises. Sheng, Wu, and Zhang (2020) argue that innovation and technological progress are the kernels of total factor productivity improvement. Therefore, it can be argued that OFDI will have a very important effect on enterprises' total factor productivity through the path of technological innovation. In fact, OFDI by Chinese enterprises can be divided into "favorable pressure gradient investment" and "reverse pressure gradient investment" according to the level of economic and technological development of the destination country. In "favorable pressure gradient investment", Chinese enterprises use their advantages to develop new markets and optimize resource allocation, maximize the use of their proprietary knowledge (Liu, Wang, \& Lu, 2016), innovate products and services suitable for new markets, and thus improve the efficiency of enterprises. While in "reverse pressure gradient investment", Chinese enterprises can embed themselves in the innovation network of developed countries by establishing overseas subsidiaries, implementing cross-border mergers and acquisitions or setting up R\&D institutions, and then absorb the advanced technological experience of developed countries through technology diffusion, learning-in-production or imitation to improve their technological innovation (Wang \& Zhang, 2020). Therefore, OFDI will have a catalytic effect on total fac- 
tor productivity through technological innovation.

According to innovation theory, the technological innovation of enterprises can be divided into two types: exploratory innovation and exploitative innovation. Therefore, OFDI will have a positive effect on enterprise productivity through exploratory innovation or exploitative innovation. Firstly, OFDI accelerates multinational enterprises' accumulation and utilization of resources such as knowledge and technology. The accumulation and utilization of these resources, not only help MNEs to conduct deep scientific research and breakthrough core technologies to bring products with disruptive innovation, improving enterprises' exploratory innovation capability (Zeira, 2011) but also helps enterprises to follow and imitate advanced foreign technologies and reversely transfer various explicit or implicit knowledge (Hang \& Zhao, 2018), which improves the exploitative innovation capability of subsidiaries and parent companies. Secondly, OFDI enterprises can shorten the communication distance with local consumers and suppliers. Xian and Ming (2018) argued that overseas mergers and acquisitions enterprises will acquire more external knowledge and thus improve their innovation mainly through mutual communication and exchange between subsidiaries, consumers, suppliers, etc. Thus, it can be concluded that OFDI can promote enterprises to conduct in-depth market research on new and existing products for multiple purposes, obtain first-hand feedback of products and technologies, strengthen communication between enterprises, consumers, and suppliers, improve the pertinence and effectiveness of their $\mathrm{R} \& \mathrm{D}$ investment, and improve their exploratory and exploitative innovation capabilities. Finally, while OFDI provides enterprises with broader market prospects, it also faces fiercer market competition and strict product standards, which will motivate enterprises to increase R\&D investment, improve their core competitiveness, and pay more attention to the reallocation of innovation resources within the enterprise to improve the quality of technological innovation (Ming et al., 2019). At the same time, enterprises will strictly control product quality, improve and upgrade products that do not meet the standards, thus enhancing their exploitative innovation capabilities. Therefore, OFDI can improve exploratory innovation by facilitating the development of new key products and services that are difficult to replicate, which can lead to significant theoretical breakthroughs and key first-mover advantages, thus increasing the total factor productivity of enterprises. It can also improve exploitative innovation by facilitating the adoption of new business processes, product standards, thus enhancing enterprise market effectiveness and total factor productivity (Zeng, Zhu, \& Sun, 2019).

Based on the above analysis, the following research hypotheses are proposed.

$\mathrm{H}_{2}$ : OFDI will enhance the total factor productivity of enterprises through technological innovation and promote high-quality development of enterprises.

$\mathrm{H}_{3}$ : Exploratory and exploitative innovations are significant paths for OFDI to promote high-quality enterprise development. It means exploratory and exploit- 
ative innovation mediates the relationship between OFDI and enterprise productivity.

\section{Equations}

\subsection{Sample Source and Selection}

Considering that the outbreak of Corona Virus Disease 2019 in December 2019 has a great impact on Chinese enterprises' outward FDI, it is an extreme outlier. In this paper, the year 2020 is not included in the test in the study design. We select Chinese companies listed on the main board of Shanghai and Shenzhen from 2008-2019 as our research subjects. We exclude companies with continuous OFDI, companies that have not formed OFDI for more than two years, ST, "ST, PT, and companies with missing data. Finally, we obtained 2742 enterprises and 15,190 observations of continuous operation. The data come mainly from CSMAR, WIND, and CCER databases.

The existing literature usually utilizes the Ministry of Commerce's Directory of Enterprises with Overseas Investment database. But this paper collates OFDI information from the overseas affiliation table of listed companies, which are more recent and accurate.

\subsection{Variables}

\subsubsection{Explained Variables: Total Factor Productivity (TFP)}

The explained variable in this paper is total factor productivity, and the common estimation methods mainly include Ordinary Least Squares (OLS), Data Envelopment Analysis (DEA), Olley-Pakes (OP), and Levinsohn-Petrin (LP). There is a great controversy in academic circles about which method can be adopted to estimate tfp more accurately. Generally speaking, the DEA method is used to estimate tfp at the macro level. OLS method has major shortcomings in calculating tfp, such as information is not comprehensive enough and it cannot effectively solve the problem of endogeneity. Compared with OLS, OP is relatively accurate in calculating tfp, but it has the problem coming from enterprises' entry into and exit from the market. LP can effectively solve the problem of endogeneity and preserve more samples. Therefore, this paper adopts the semi-parametric estimation method proposed by Levinsohn and Petrin (2003) to calculate the tfp of enterprises and conducts stability tests using OP. Specifically, LP estimates the coefficients of labor, capital, and intermediate inputs in two steps. In the first step, the OLS is adopted to estimate the coefficients of labor by using the approximation of higher-order polynomials of capitals and intermediate inputs. In the second step, the coefficients of capitals and intermediate inputs are estimated using the labor coefficients estimated in the first step, and finally, the effective estimation of productivity is derived.

\subsubsection{Explanatory Variables: Outward Foreign Direct Investment (OFDI)} The main explanatory variable in this paper is corporate OFDI, shown as a dummy variable. The year when the enterprise has OFDI takes the value of 1 and 
the opposite is 0 .

\subsubsection{Mediating Variables: Technological Innovation, Exploratory Innovation, and Exploitative Innovation}

The mediating variables in this paper are technological innovation (inn), exploratory innovation (eri), and exploitative innovation (eti). In quantitative analysis, existing studies mostly portray enterprises' technological innovation in terms of $R \& D$ investment and patent output. Compared with patent output, R\&D investment is more time-sensitive and can better reflect a company's willingness to innovate. Therefore, this paper uses $\mathrm{R} \& \mathrm{D}$ investment as a proxy variable for technological innovation. Specifically, the total number of R\&D funds is measured as the enterprise's technological innovation.

In addition, this paper classifies exploratory innovation (eri) and exploitative innovation (eti) by motives of innovation. According to the cost treatment in the research stage stated in Accounting Standards for Business No.6-Intangible Assets and studies by Bi, Zhai and Jiang (2017), expensed R\&D investment is used to quantify the exploratory innovation and the capitalized R\&D investment is used to quantify the exploitative innovation.

\subsubsection{Control Variables}

This paper selects control variables at the enterprise financial and trade levels to control the impact of enterprises' OFDI on high-quality development. Table 1 shows the definition of each variable.

\subsection{Propensity Score Matching (PSM)-Multi-Temporal Difference-in-Differences (DID)}

In order to effectively test the promotion effect of OFDI on enterprise productivity, based on Difference-in-Differences (DID), this paper divides the experimental group and the control group according to whether there is OFDI in the sample period. $d u$ is used to show whether there is OFDI in the sample period. Value 1 indicates there is OFDI, value 0 indicates otherwise. ofd $i$ is used to show period of OFDI. Value1 indicates the period when OFDI exists, value 0 indicates otherwise. $\Delta t f p_{i}^{1}$ indicates the change in productivity in the sample period when enterprise was making OFDI. $\Delta t f p_{i}^{0}$ shows the change in productivity in the sample period when enterprise did not make OFDI. At this point, the actual impact of OFDI on the total factor productivity of the enterprises $\phi$ is:

$$
\phi=E\left(\phi_{i} \mid d u_{i}=1\right)=E\left(\Delta t f p_{i}^{1} \mid d u_{i}=1\right)-E\left(\Delta t f p_{i}^{0} \mid d u_{i}=1\right)
$$

Given that it is not possible to observe the total factor productivity of OFDI if enterprises "had not invested", i.e., $E\left(\Delta t f p_{i}^{0} \mid d u_{i}=1\right)$ is actually an unobservable variable. Therefore, in this paper, we use Propensity Score Matching (PSM) to construct the most similar control group in order to estimate $\phi$. Experimental group and control group are similar in characteristics and probability of investment before the investment starts. In this way, we can replace 
Table 1. Definition of variables.

\begin{tabular}{|c|c|c|c|}
\hline $\begin{array}{l}\text { Variable } \\
\text { Type }\end{array}$ & Variables & $\begin{array}{l}\text { Variable } \\
\text { Symbols }\end{array}$ & Variable Description \\
\hline $\begin{array}{l}\text { Explained } \\
\text { variable }\end{array}$ & $\begin{array}{l}\text { Total factor } \\
\text { productivity }\end{array}$ & $\operatorname{tfp}$ & $\begin{array}{l}\text { The natural logarithm is taken after } \\
\text { calculated by LP }\end{array}$ \\
\hline $\begin{array}{l}\text { Explanatory } \\
\text { variable }\end{array}$ & $\begin{array}{l}\text { Outward } \\
\text { foreign direct } \\
\text { investment }\end{array}$ & ofdi & $\begin{array}{l}\text { The year when OFDI exists assigned a } \\
\text { value of } 1 \text {, otherwise assigned a } \\
\text { value of } 0\end{array}$ \\
\hline \multirow{3}{*}{$\begin{array}{l}\text { Mediating } \\
\text { variables }\end{array}$} & $\begin{array}{l}\text { Technological } \\
\text { innovation }\end{array}$ & inn & $\begin{array}{l}\text { ln (total amount of enterprise R\&D } \\
\text { investment }+1 \text { ) }\end{array}$ \\
\hline & $\begin{array}{l}\text { Exploratory } \\
\text { Innovation }\end{array}$ & eri & $\begin{array}{l}\text { ln (amount of expensed R\&D } \\
\text { investment (expenditure) }+1 \text { ) }\end{array}$ \\
\hline & $\begin{array}{l}\text { Exploitative } \\
\text { innovation }\end{array}$ & eti & $\begin{array}{l}\text { ln (amount of capitalized R\&D } \\
\text { investment (expenditure) }+1 \text { ) }\end{array}$ \\
\hline \multirow{8}{*}{$\begin{array}{l}\text { Control } \\
\text { variables }\end{array}$} & Enterprise size & size & $\ln ($ net fixed assets +1$)$ \\
\hline & Company age & age & ln (current year - year of listing +1 ) \\
\hline & $\begin{array}{l}\text { Debt to asset } \\
\text { ratio }\end{array}$ & lev & Total liabilities/total assets \\
\hline & $\begin{array}{l}\text { Return on total } \\
\text { assets }\end{array}$ & roa & Net profit/average total assets \\
\hline & $\begin{array}{l}\text { Growth rate of } \\
\text { operating } \\
\text { income }\end{array}$ & growth & $\begin{array}{l}\text { Difference between the operating } \\
\text { income of the current period and that } \\
\text { of the previous year/operating } \\
\text { income of previous period }\end{array}$ \\
\hline & Export & export & $\begin{array}{l}\text { ln (Enterprise overseas sales } \\
\text { revenue }+1)\end{array}$ \\
\hline & Year & year & $\begin{array}{l}\text { Dummy variable of year to control the } \\
\text { impact of macro-environmental } \\
\text { changes }\end{array}$ \\
\hline & Enterprise & stkcd & $\begin{array}{l}\text { Dummy variable of enterprise to } \\
\text { control inter-enterprise effects }\end{array}$ \\
\hline
\end{tabular}

$E\left(\Delta t f p_{i}^{0} \mid d u_{i}=1\right)$ with the approximation of $E\left(\Delta t f p_{i}^{0} \mid d u_{i}=0\right)$. At this point, Equation (1) becomes:

$$
\phi=E\left(\phi_{i} \mid d u_{i}=1\right)=E\left(\Delta t f p_{i}^{1} \mid d u_{i}=1\right)-E\left(\Delta t f p_{i}^{0} \mid d u_{i}=0\right)
$$

The "new sample" obtained by the PSM method can effectively reduce the pre-OFDI differences between the experimental and control group so that they can better satisfy the common trend assumption and eliminate the sample selection bias caused by enterprise heterogeneity. Then, the endogeneity problem caused by omitted variables (especially unobservable variables) is solved by the Difference-in-Differences (DID) method, which results in the "net effect" of OFDI on enterprise productivity. 
However, there are differences in the year when enterprises start out OFDI, so the traditional DID model is difficult to meet the estimation needs. This paper borrows from Beck et al. (2010) and tests by using a multi-temporal DID regression model, which is designed as follows:

$$
\begin{aligned}
t f p_{i t}= & \beta_{0}+\beta_{1} \text { ofdi }_{i t}+\beta_{2} \text { size }_{i t}+\beta_{3} \text { age }_{i t}+\beta_{4} \text { lev }_{i t}+\beta_{5} \text { roa }_{i t} \\
& +\beta_{6} \text { growth }_{i t}+\beta_{7} \text { export } \\
i t & +\sum \text { year }+\sum s t k c d+\varepsilon_{1 i t}
\end{aligned}
$$

In Model (1), $t f p_{i t}$ is the logarithm of annual total factor productivity of the enterprise $i$ in the year $t$. Meaning of ofdi is consistent with that in the previous discussion. The coefficient of $\beta_{1}$, the parameter of most interest of this paper, indicates the actual impact of OFDI on enterprise productivity; size $_{i t}$, age $_{i t}$, lev $_{i t}$, roa $_{i t}$, growth $_{i t}$, export $t_{i t}$ denote enterprise size, enterprise age, debt to asset ratio, return on total assets, operating income growth rate, and exports respectively. $\sum$ year refers to control of year fixed effects, $\sum$ stkcd means control of enterprise fixed effects, and $\varepsilon_{i t}$ denotes the random errorterm.

\section{Analysis of the Effect of OFDI in Promoting High-Quality Development of Enterprises}

\subsection{Descriptive Statistics}

Table 2 shows the results of descriptive statistics for each variable. In terms of the mean and median of total factor productivity, OFDI enterprises are 0.072 and 0.119 higher than non-OFDI enterprises respectively, indicating that OFDI has an important impact on the total factor productivity of enterprises and has an effect on the quality development of enterprises. According to the previous discussion, this may be the result of the "self-selection effect" of enterprises, or it may come from the learning effect of OFDI. However, in this case, if the two types of enterprises are directly tested by multiple regressions, it is impossible to identify which one brings about the innovation and productivity improvement of enterprises, the "self-selection effect" or the learning effect of OFDI. In this paper, the PSM-DID method is used to avoid the interference of self-selection effect and endogeneity, so as to precisely test the impact of OFDI on enterprise productivity.

\subsection{Propensity Score Matching Results and Analysis}

Based on the description of the PSM method, the nearest neighbor matching method is selected. The matching ratios in this paper are 1:1 and 1:2 and matched year by year to ensure the robustness of the study. Based on the studies of Jiang and Jiang (2014), this paper selects enterprise total factor productivity, capital intensity, and the number of employees as matching variables. In this paper, we select enterprises that started OFDI in 2009-2019, and in order to avoid the "self-selection problem", we need to proportionally match the characteristic variables of enterprises in the previous year with enterprises that have 
Table 2. Descriptive statistics of variables.

\begin{tabular}{|c|c|c|c|c|c|c|c|c|c|}
\hline Variables & Symbols & Observation & Mean & $\begin{array}{l}\text { Standard } \\
\text { Deviation }\end{array}$ & Minimum & $\begin{array}{c}\text { Lower } \\
\text { quartile }\end{array}$ & Median & $\begin{array}{c}\text { Upper } \\
\text { quartile }\end{array}$ & Maximum \\
\hline \multirow{11}{*}{$\begin{array}{c}\text { OFDI } \\
\text { Enterprises }\end{array}$} & $\mathrm{tfp}$ & 7296 & 8.201 & 0.956 & 4.942 & 7.555 & 8.120 & 8.744 & 12.319 \\
\hline & ofdi & 7296 & 0.768 & 0.422 & 0.000 & 1.000 & 1.000 & 1.000 & 1.000 \\
\hline & inn & 7296 & 18.051 & 1.368 & 0.000 & 17.243 & 18.045 & 18.879 & 23.787 \\
\hline & eri & 7296 & 17.024 & 4.070 & 0.000 & 16.933 & 17.837 & 18.683 & 27.496 \\
\hline & eti & 7296 & 4.829 & 7.657 & 0.000 & 0.000 & 0.000 & 14.861 & 22.863 \\
\hline & size & 7296 & 20.276 & 1.481 & 14.231 & 19.395 & 20.182 & 21.114 & 27.279 \\
\hline & age & 7296 & 2.017 & 0.623 & 1.099 & 1.609 & 1.946 & 2.485 & 3.332 \\
\hline & lev & 7296 & 0.415 & 0.194 & 0.011 & 0.261 & 0.409 & 0.560 & 1.687 \\
\hline & roa & 7296 & 0.066 & 0.308 & -21.998 & 0.034 & 0.074 & 0.122 & 1.026 \\
\hline & growth & 7296 & 0.545 & 22.060 & -0.918 & 0.014 & 0.146 & 0.308 & 1878.372 \\
\hline & export & 7296 & 6.473 & 5.032 & 0.000 & 0.000 & 8.704 & 10.625 & 16.280 \\
\hline \multirow{11}{*}{$\begin{array}{l}\text { Non-OFDI } \\
\text { enterprises }\end{array}$} & $\mathrm{tfp}$ & 7894 & 8.129 & 1.013 & 5.325 & 7.423 & 8.001 & 8.685 & 11.769 \\
\hline & ofdi & 7894 & 0.000 & 0.000 & 0.000 & 0.000 & 0.000 & 0.000 & 0.000 \\
\hline & inn & 7894 & 17.648 & 1.652 & 0.000 & 16.782 & 17.682 & 18.517 & 25.025 \\
\hline & eri & 7894 & 16.679 & 3.997 & 0.000 & 16.414 & 17.459 & 18.350 & 27.624 \\
\hline & eti & 7894 & 3.824 & 6.988 & 0.000 & 0.000 & 0.000 & 0.000 & 23.257 \\
\hline & size & 7894 & 20.411 & 1.624 & 13.588 & 19.359 & 20.246 & 21.292 & 26.658 \\
\hline & age & 7894 & 2.259 & 0.643 & 1.099 & 1.792 & 2.398 & 2.833 & 3.401 \\
\hline & lev & 7894 & 0.413 & 0.198 & 0.008 & 0.256 & 0.405 & 0.562 & 1.352 \\
\hline & roa & 7894 & 0.062 & 0.190 & -7.220 & 0.027 & 0.066 & 0.116 & 1.294 \\
\hline & growth & 7894 & 0.215 & 1.896 & -0.982 & -0.020 & 0.101 & 0.247 & 96.024 \\
\hline & export & 7894 & 4.949 & 5.189 & 0.000 & 0.000 & 2.965 & 10.011 & 17.089 \\
\hline
\end{tabular}

never conducted OFDI in that year. Therefore, the actual matching interval in this paper is 2008-2018. Taking the 1:1 matching ratio as an example, the specific treatment is as follows:

1) For the enterprises that started OFDI in 2009, matching is performed using the characteristic variables of the corresponding enterprises in 2008. Firstly, the probit model is applied to predict the probability of OFDI for each enterprise in that year based on the matching variables, and then the unique non-OFDI enterprise is found for each OFDI enterprise according to the predicted probability. After matching, the observations that do not satisfy the common region assumption and are not successfully matched are excluded. Thus, a control group of enterprises with very similar characteristics to those in the experimental group is obtained. In this way, the matched dataset of 2009 is formed. Then, the 2009 dataset is tested for balance.

2) The sample of enterprises from 2010-2019 was further matched year by 
year as described above and tested for balance year by year.

3) Then the corresponding enterprises from 2009-2019 are found based on the enterprises in the experimental and control groups from 2008-2018. The abovematched datasets of each year are combined to form the basic dataset after Propensity Score Matching.

Table 3 shows the balance test results of the basic dataset. It can be seen that the absolute values of standard deviations of all matching variables after PSM do not exceed 3\%, which indicates that this paper is scientific in the selection of matching variables and methods. Meanwhile, the p-values after matching were $0.132,0.643,0.709,0.120,0.102$, and 0.189 , which were not significant, indicating that there was no significant difference between the characteristic variables of the enterprises in the experimental and control groups after PSM, which was consistent with the parallel trend test.

Figure 1 shows the kernel density function graph of the experimental and control group enterprises before and after matching. As shown in the figure, there is a significant difference between the two groups of enterprises before matching by PSM method: The peak point of the experimental group is about $(0.42,2.40)$, and the peak point of the control group is about $(0.68,2.50)$. While after matching the enterprises of the experimental and control groups selected according to the PSM method, the kernel density functions of the two groups of enterprises nearly overlap, with the peak point of the experimental group being about $(0.46,2.41)$, and that of the control group about $(0.46,2.40)$, which is not

Table 3. PSM equilibrium test results.

\begin{tabular}{|c|c|c|c|c|c|c|}
\hline \multirow[b]{2}{*}{ Variables } & \multirow{2}{*}{$\begin{array}{c}\text { Before } \\
\text { and after } \\
\text { Matching }\end{array}$} & \multicolumn{2}{|c|}{ Mean } & \multirow{2}{*}{$\begin{array}{c}\text { Standard } \\
\text { Deviation } \\
\quad \%)\end{array}$} & \multirow[b]{2}{*}{ t-value } & \multirow[b]{2}{*}{$\mathrm{P}$-value } \\
\hline & & $\begin{array}{l}\text { Experimental } \\
\text { group }\end{array}$ & $\begin{array}{l}\text { Control } \\
\text { group }\end{array}$ & & & \\
\hline \multirow{2}{*}{$\operatorname{Tfp}_{\mathrm{t}-1}$} & Before & 8.110 & 8.068 & 4.2 & 2.57 & 0.010 \\
\hline & After & 8.103 & 8.129 & -2.6 & -1.51 & 0.132 \\
\hline \multirow{2}{*}{$\mathrm{Ci}_{\mathrm{t}-1}$} & Before & 2.294 & 2.299 & -0.2 & -0.10 & 0.921 \\
\hline & After & 2.257 & 2.242 & 0.5 & 0.46 & 0.643 \\
\hline \multirow{2}{*}{ Employeest-1 } & Before & 7.716 & 7.781 & -5.4 & -3.33 & 0.001 \\
\hline & After & 7.714 & 7.706 & 0.6 & 0.37 & 0.709 \\
\hline \multirow{2}{*}{ Age $_{t-1}$} & Before & 1.837 & 2.115 & -37.6 & -23.12 & 0.000 \\
\hline & After & 1.843 & 1.862 & -2.6 & -1.55 & 0.120 \\
\hline \multirow{2}{*}{ Export $_{\mathrm{t}-1}$} & Before & 7.455 & 5.743 & 35.2 & 21.66 & 0.000 \\
\hline & After & 7.430 & 7.361 & -2.6 & -1.55 & 0.379 \\
\hline \multirow{2}{*}{ Oprt-1 } & Before & 0.090 & 0.084 & 2.6 & 1.64 & 0.102 \\
\hline & After & 0.093 & 0.093 & -0.2 & -0.14 & 0.885 \\
\hline \multirow{2}{*}{ Roat-1 } & Before & 0.080 & 0.073 & 5.3 & 3.27 & 0.001 \\
\hline & After & 0.081 & 0.079 & 1.8 & 1.31 & 0.189 \\
\hline
\end{tabular}


before

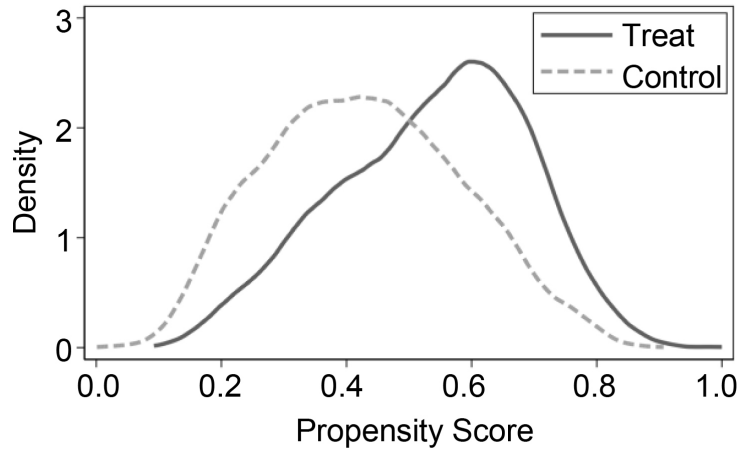

after

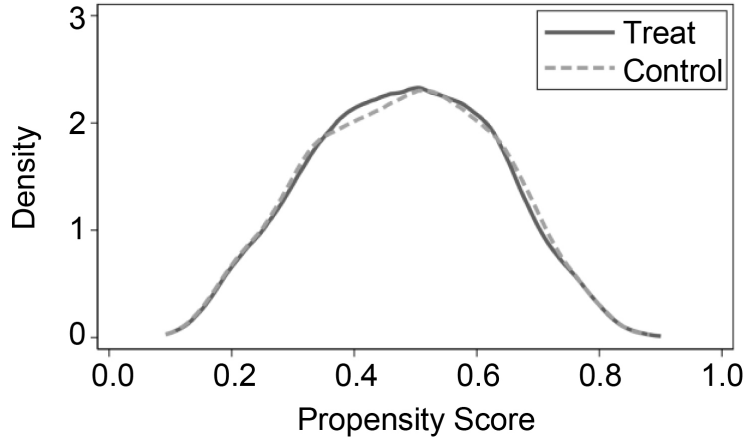

Figure 1. Graph of the kernel density function before and after matching.

significantly different and the matching effect is more satisfactory. In this way, the estimation bias caused by the "self-selection problem" of the sample can be better resolved.

\subsection{Multi-Temporal Difference-in-Differences (DID) Estimation Results and Analysis}

\subsubsection{Baseline Regression Test}

Table 4 shows the results of the baseline regression test for the impact of OFDI on enterprise productivity or high-quality development. Among them, Column (1) and Column (2) are the results of the benchmark tests of a 1:1 matched sample by using the PSM method. For robustness, Column (3) and Column (4) are the results of the benchmark test with 1:2 matching.

Column (1) in Table 4 shows that the regression coefficient of outward direct investment (OFDI) is significantly positive at the level of $1 \%(0.183, \mathrm{p}<0.01)$. The result indicates that OFDI can improve the productivity of enterprises and contribute to their high-quality development. Therefore, $\mathrm{H}_{1}$ is supported. Column (2) adds control variables to the estimated equation, and the regression coefficient of outward direct investment (OFDI) is found to be significantly positive at the level of $1 \%(0.152, \mathrm{p}<0.01)$, further supporting the above findings. As discussed in the previous part, this may be due to the optimization of MNEs' structure, the international diffusion of knowledge and technology, or possibly 
Table 4. Baseline regression results.

\begin{tabular}{|c|c|c|c|c|}
\hline \multirow{3}{*}{ Matching ratio } & \multicolumn{2}{|c|}{$1: 1$} & \multicolumn{2}{|c|}{$1: 2$} \\
\hline & $\mathrm{tfp}$ & $\mathrm{tfp}$ & $\mathrm{tfp}$ & $\mathrm{tfp}$ \\
\hline & (1) & (2) & (3) & (4) \\
\hline \multirow{2}{*}{ ofdi } & $0.183^{\star * \star}$ & $0.152^{* * *}$ & $0.190^{\star * *}$ & $0.154^{* * *}$ \\
\hline & $(6.01)$ & $(5.57)$ & $(7.30)$ & $(6.37)$ \\
\hline \multirow{2}{*}{ size } & & $0.040^{*}$ & & $0.039^{* *}$ \\
\hline & & (1.68) & & $(2.00)$ \\
\hline \multirow{2}{*}{ age } & & $0.163^{\star * *}$ & & $0.097^{\star *}$ \\
\hline & & $(3.18)$ & & $(2.20)$ \\
\hline \multirow{2}{*}{ lev } & & $1.058^{* * *}$ & & $0.897^{\star * *}$ \\
\hline & & $(8.97)$ & & $(8.62)$ \\
\hline \multirow{2}{*}{ roa } & & $0.495^{\star * *}$ & & $0.253^{* *}$ \\
\hline & & $(4.00)$ & & $(2.09)$ \\
\hline \multirow{2}{*}{ growth } & & $0.000^{*}$ & & $0.042^{\star * *}$ \\
\hline & & $(1.74)$ & & $(3.28)$ \\
\hline \multirow{2}{*}{ export } & & $0.011^{\star * *}$ & & $0.008^{\star * *}$ \\
\hline & & $(3.66)$ & & $(3.55)$ \\
\hline \multirow{2}{*}{ Constant term } & $7.611^{\star \star \star}$ & $6.103^{* * *}$ & $7.618^{\star * *}$ & $6.318^{\star * *}$ \\
\hline & $(145.17)$ & (13.29) & $(206.81)$ & (16.97) \\
\hline Year & Yes & Yes & Yes & Yes \\
\hline Enterprise & Yes & Yes & Yes & Yes \\
\hline Observations & 7393 & 7393 & 10,761 & 10,761 \\
\hline$R^{2}$ & 0.275 & 0.380 & 0.272 & 0.372 \\
\hline $\mathrm{F}$ & 67.047 & 58.118 & 92.572 & 75.125 \\
\hline
\end{tabular}

The standard errors for robust clustering are in parentheses. ${ }^{*}{ }^{* *}$, and ${ }^{* *}$ indicate significant at the level of $10 \%, 5 \%$, and $1 \%$ respectively. Same as below. This paper also tests the data for 1:3 and 1:5 matching ratios, showing stable results, which are not presented due to space limitations.

too intense overseas competition. Among the control variables, the effect of enterprise size on productivity is significantly positive, which may be explained by the fact that the larger the enterprise-scale, the more scientific its management mode, the more detailed the division of labors, the longer and more stable the control level of the enterprise pyramid, and the easier to obtain higher productivity. The effect of enterprise age on productivity is significantly positive and the possible reason is that with the increase of operating years, the enterprise may accumulate rich production experience and become more stable in organization and management, so the productivity is higher. The effect of debt to asset ratio (lev) on productivity is significantly positive, perhaps because enterprises with high debt financing have more capital and a better governance structure 
due to the introduction of creditors, which leads to more outstanding performance in the introduction of highly-qualified talents and innovation, leading to higher enterprise productivity. The coefficient of return on total assets (roa) has a significant positive effect on productivity, indicating that the stronger the profitability enterprises have, the higher their productivity level is. The coefficient of the growth rate of operating income (growth) is significantly positive, indicating that the productivity level of enterprises with strong growth ability is relatively higher. The coefficient of export (export) has a significant positive effect on productivity, indicating that exporting enterprises have higher productivity levels, which may be explained by the fact that enterprises can release excess capacity and obtain more capital and technology through exporting, thus contributing to productivity improvement.

\subsubsection{Heterogeneity Test}

1) Tests based on different equity natures

To examine the asymmetric effects of OFDI effects at the individual level, this paper explores the effects of OFDI on different types of firms by examining heterogeneity in two aspects: equity natures and regional characteristics.

Based on the nature of equity, the paper analyzes the enterprises into two categories, SOEs and private enterprises, and the regression results are reported in columns (1) to (2) in Table 5. The coefficients are significantly higher for SOEs' OFDI than for private enterprises. And the F-value of the Chow test for both groups of samples is $10.47(\mathrm{p}=0.000)$. The coefficients are significantly different and robust, which means that OFDI has a better effect on the productivity of SOEs than on private enterprises. This finding suggests that although OFDI can significantly increase the productivity of enterprises of all types of ownership, SOEs who can obtain greater advantages than private enterprises in terms of government approval and financial support can afford the fixed costs coming from internationalization strategies and obtain more convenient investment environment. Therefore, when entering overseas markets, SOEs may have an advantage in project selection and invest in more promising projects or projects with higher added value, thus bringing greater efficiency gains. Furthermore, Chinese SOEs are usually industry leaders and they usually focus on projects with relatively high technical requirements when making a foreign direct investment, while private enterprises mainly focus on projects with lower technical requirements, so SOEs can bring more efficiency gains when making outward foreign direct investment. Finally, since SOEs usually have advantages in technology, equipment, and human resources when operating in China, they are usually more capable of digesting and absorbing new technology and transforming technology after acquiring it through overseas investment, so SOEs can better promote their high-quality development through OFDI.

2) Tests based on different regional characteristics

China's development is extremely regionally unbalanced, with rapid development in the east, slower development in the center, and lagging development in 
Table 5. Heterogeneity test-productivity effect of OFDI.

\begin{tabular}{|c|c|c|c|c|c|c|c|c|c|c|c|}
\hline & State-owned & Private & East & Central & West & $\begin{array}{l}\text { Central } \\
\text { government } \\
\text { policy } \\
\text { support }\end{array}$ & $\begin{array}{c}\text { Non-central } \\
\text { government } \\
\text { policy } \\
\text { support }\end{array}$ & $\begin{array}{c}\text { Central } \\
\text { government } \\
\text { policy } \\
\text { support \& } \\
\text { manufacturing }\end{array}$ & $\begin{array}{c}\text { Central } \\
\text { government } \\
\text { policy } \\
\text { support \& } \\
\text { service } \\
\text { industry }\end{array}$ & $\begin{array}{c}\text { Non-policy } \\
\text { support \& } \\
\text { manufacturing }\end{array}$ & $\begin{array}{c}\text { Non-central } \\
\text { government } \\
\text { policy } \\
\text { support \& } \\
\text { service } \\
\text { industry }\end{array}$ \\
\hline & tfp & tfp & tfp & tfp & tfp & tfp & tfp & tfp & tfp & tfp & tfp \\
\hline & (1) & (2) & (3) & (4) & (5) & (6) & (7) & (8) & (9) & (10) & (11) \\
\hline ofdi & $\begin{array}{c}0.136^{* * *} \\
(3.41)\end{array}$ & $\begin{array}{c}0.105^{* * *} \\
(2.89)\end{array}$ & $\begin{array}{c}0.164^{\star * \star} \\
(4.43)\end{array}$ & $\begin{array}{l}0.140^{* *} \\
(2.15)\end{array}$ & $\begin{array}{l}0.175^{* *} \\
(2.14)\end{array}$ & $\begin{array}{c}0.136^{* * *} \\
(4.27)\end{array}$ & $\begin{array}{c}0.161^{\star * *} \\
(2.67)\end{array}$ & $\begin{array}{c}0.094^{* * *} \\
(3.00)\end{array}$ & $\begin{array}{l}0.190^{* *} \\
(2.23)\end{array}$ & $\begin{array}{l}0.076 \\
(1.27)\end{array}$ & $\begin{array}{l}0.216^{* *} \\
(2.08)\end{array}$ \\
\hline size & $\begin{array}{c}0.108^{* * *} \\
(3.59)\end{array}$ & $\begin{array}{l}0.017 \\
(0.54)\end{array}$ & $\begin{array}{l}-0.003 \\
(-0.11)\end{array}$ & $\begin{array}{l}0.055 \\
(0.70)\end{array}$ & $\begin{array}{c}0.172^{* * *} \\
(2.92)\end{array}$ & $\begin{array}{l}0.008 \\
(0.28)\end{array}$ & $\begin{array}{l}0.033 \\
(0.53)\end{array}$ & $\begin{array}{c}0.085^{* * *} \\
(2.92)\end{array}$ & $\begin{array}{c}-0.144^{* * *} \\
(-3.03)\end{array}$ & $\begin{array}{l}0.060 \\
(1.63)\end{array}$ & $\begin{array}{l}-0.079 \\
(-1.64)\end{array}$ \\
\hline age & $\begin{array}{l}0.144^{\star} \\
(1.65)\end{array}$ & $\begin{array}{l}0.103 \\
(1.23)\end{array}$ & $\begin{array}{c}0.170^{* * *} \\
(2.63)\end{array}$ & $\begin{array}{l}0.191 \\
(1.50)\end{array}$ & $\begin{array}{l}0.091 \\
(0.61)\end{array}$ & $\begin{array}{c}0.167^{* * *} \\
(2.84)\end{array}$ & $\begin{array}{l}0.170 \\
(1.51)\end{array}$ & $\begin{array}{l}0.089 \\
(1.46)\end{array}$ & $\begin{array}{l}0.180 \\
(0.93)\end{array}$ & $\begin{array}{c}0.325^{* * *} \\
(3.65)\end{array}$ & $\begin{array}{l}-0.246 \\
(-1.12)\end{array}$ \\
\hline lev & $\begin{array}{c}1.096^{* * *} \\
(6.28)\end{array}$ & $\begin{array}{c}0.840^{* * *} \\
(5.54)\end{array}$ & $\begin{array}{c}1.068^{* * *} \\
(7.81)\end{array}$ & $\begin{array}{c}0.883^{\star * *} \\
(3.78)\end{array}$ & $\begin{array}{c}0.958^{* * *} \\
(2.82)\end{array}$ & $\begin{array}{c}0.936^{* * *} \\
(6.91)\end{array}$ & $\begin{array}{c}0.790^{* * *} \\
(4.05)\end{array}$ & $\begin{array}{c}0.834^{* * *} \\
(6.85)\end{array}$ & $\begin{array}{c}0.950^{* * *} \\
(3.24)\end{array}$ & $\begin{array}{c}0.493^{* * *} \\
(3.40)\end{array}$ & $\begin{array}{c}1.630^{* * *} \\
(5.39)\end{array}$ \\
\hline roa & $\begin{array}{l}0.338^{* *} \\
(2.51)\end{array}$ & $\begin{array}{c}0.461^{* * *} \\
(2.92)\end{array}$ & $\begin{array}{c}0.815^{\star * *} \\
(7.59)\end{array}$ & $\begin{array}{l}0.246^{* *} \\
(2.10)\end{array}$ & $\begin{array}{c}0.221^{* * *} \\
(3.76)\end{array}$ & $\begin{array}{c}0.608^{\star * *} \\
(5.14)\end{array}$ & $\begin{array}{l}0.368^{* *} \\
(2.53)\end{array}$ & $\begin{array}{c}0.606^{\star * *} \\
(4.81)\end{array}$ & $\begin{array}{c}0.578^{\star * *} \\
(3.32)\end{array}$ & $\begin{array}{c}0.638^{\star * *} \\
(3.12)\end{array}$ & $\begin{array}{c}0.756^{* * *} \\
(3.62)\end{array}$ \\
\hline growth & $\begin{array}{c}0.088^{* * *} \\
(5.09)\end{array}$ & $\begin{array}{l}0.027^{\star} \\
(1.94)\end{array}$ & $\begin{array}{c}0.000^{* *} \\
(2.03)\end{array}$ & $\begin{array}{l}0.072^{\star} \\
(1.70)\end{array}$ & $\begin{array}{c}0.056^{* * *} \\
(3.54)\end{array}$ & $\begin{array}{c}0.059^{* * *} \\
(4.11)\end{array}$ & $\begin{array}{c}0.000^{* * *} \\
(3.65)\end{array}$ & $\begin{array}{c}0.053^{* * *} \\
(3.86)\end{array}$ & $\begin{array}{c}0.130^{* * *} \\
(4.13)\end{array}$ & $\begin{array}{c}0.102^{\star * *} \\
(5.37)\end{array}$ & $\begin{array}{l}0.000 \\
(0.61)\end{array}$ \\
\hline export & $\begin{array}{l}0.006 \\
(1.52)\end{array}$ & $\begin{array}{c}0.015^{* * *} \\
(4.12)\end{array}$ & $\begin{array}{c}0.012^{* * *} \\
(3.22)\end{array}$ & $\begin{array}{l}0.011^{* *} \\
(2.12)\end{array}$ & $\begin{array}{l}0.001 \\
(0.13)\end{array}$ & $\begin{array}{c}0.011^{* * *} \\
(3.09)\end{array}$ & $\begin{array}{l}0.005 \\
(1.14)\end{array}$ & $\begin{array}{c}0.013^{* * *} \\
(3.73)\end{array}$ & $\begin{array}{l}-0.001 \\
(-0.09)\end{array}$ & $\begin{array}{l}0.006 \\
(1.31)\end{array}$ & $\begin{array}{l}0.007 \\
(0.83)\end{array}$ \\
\hline $\begin{array}{c}\text { Constant } \\
\text { term }\end{array}$ & $\begin{array}{c}5.074^{\star * *} \\
(8.42)\end{array}$ & $\begin{array}{l}6.460^{* * *} \\
(10.64)\end{array}$ & $\begin{array}{l}6.862^{\star * *} \\
(14.27)\end{array}$ & $\begin{array}{c}5.872^{\star * *} \\
(4.10)\end{array}$ & $\begin{array}{c}3.614^{* * *} \\
(3.13)\end{array}$ & $\begin{array}{l}6.684^{* * *} \\
(12.89)\end{array}$ & $\begin{array}{c}6.665^{* * *} \\
(5.46)\end{array}$ & $\begin{array}{c}5.241^{* * *} \\
(9.37)\end{array}$ & $\begin{array}{c}10.174^{* * *} \\
(9.83)\end{array}$ & $\begin{array}{c}5.929^{* * *} \\
(8.09)\end{array}$ & $\begin{array}{c}8.897^{* * *} \\
(8.10)\end{array}$ \\
\hline Year & Yes & Yes & Yes & Yes & Yes & Yes & Yes & Yes & Yes & Yes & Yes \\
\hline Enterprise & Yes & Yes & Yes & Yes & Yes & Yes & Yes & Yes & Yes & Yes & Yes \\
\hline Observations & 2463 & 4336 & 4722 & 1040 & 848 & 4856 & 2053 & 3843 & 688 & 1337 & 498 \\
\hline$R^{2}$ & 0.428 & 0.406 & 0.422 & 0.445 & 0.446 & 0.446 & 0.292 & 0.469 & 0.526 & 0.481 & 0.291 \\
\hline $\mathrm{F}$ & 25.923 & 37.989 & 39.596 & 15.620 & 20.974 & 45.542 & 14.000 & 41.127 & 15.548 & 31.180 & 6.316 \\
\hline
\end{tabular}

The standard errors for robust clustering are in parentheses. This paper also tested the data for 1:2, 1:3, and 1:5 matching ratios, and the results were robust and will not be repeated due to space limitations.

the west. Based on this, this paper divides China into three regions: eastern, central, and western. Column (3) to (5) in Table 5 reports the regression results when disaggregated by region. It shows that OFDI significantly boosts enterprise productivity, but the magnitudes of the coefficients vary with the strongest productivity-boosting effect of OFDI in the western region, which remains consistent with the existing literature. The possible reasons are that on the one hand, the western region has a stronger absorptive capacity due to its more backward technology level, thus showing a latecomer advantage in technological innovation and generating higher efficiency gains. Moreover, policies such as the Western 
Development Plan promote investment in $\mathrm{R} \& \mathrm{D}$, human capital, management innovation, and resource allocation in the western region, facilitating enterprises to absorb more positive factors from OFDI as a way to enhance the total factor productivity of enterprises.

3) Tests based on different industry policies

Productivity improvement is not solely determined by enterprise-specific resources and specific conditions but also depends on central government policy support and the institutional environment. According to the institutional-based view, national policies are important determinants of resource allocation and industrial rules. Therefore, enterprise productivity can be affected by central government policies. New institutional economics argues that the institutional environment in which enterprises in emerging economies operate is an important factor influencing their cross-country behavior where institutional factors can directly affect the performance of enterprises and their efficiency improvement. So this paper further tests whether OFDI will promote high-quality enterprise development based on the central government's policy attitude toward industry development in the next five years. Specifically, this paper defines industries encouraged by the central government in the next five-year plan as the sample with central government policy support and others as a sample without central government policy support.

Column (6) to (7) in Table 5 shows that OFDI significantly improves the total factor productivity of enterprises regardless of whether the industry is supported by government policy or not. This result indicates that even without central government policy support, cross-border investment can bring a productivity boost to enterprises. Enterprises can also improve their overall development quality through OFDI with mechanisms such as resource allocation optimization and management mechanism innovation. Furthermore, this paper subdivides the sample into the manufacturing industry and service industry according to the 2012 China Securities Regulatory Commission's Industry Classification Criteria. Column (8) to (11) shows that for manufacturing and service industries with central government policy support, OFDI can significantly boost their productivity, while for enterprises without central government policy support, OFDI has a significant effect on productivity enhancement only for the service industry. A possible explanation for this is that manufacturing enterprises have to bear much bigger fixed costs from OFDI than enterprises in the service industry, so in this case, central government policy support is crucial.

\section{Analysis of the Mechanism of OFDI for High-Quality Development of Enterprises}

OFDI may affect the enhancement of total factor productivity through mechanisms such as personnel mobility, headquarters services, resource allocation, and technology feedback, and these multiple mechanisms are closely related to enterprise technology innovation. In other words, technological innovation should 
be an important mechanism and fundamental way for OFDI to affect total factor productivity. Therefore, this paper will further explore the mechanisms related to the impact of OFDI on the total factor productivity of enterprises from the perspective of technological innovation, so as to deeply analyze the motives that can promote the high-quality development of OFDI enterprises. For this, the study refers to the method of Weng, Zhang, Hou and Liu (2004) and further develops models (2)-(3) on the basis of model (1), in order to test the mediating effect of technological innovation on the impact of OFDI on total factor productivity. In addition, according to Gan and Qi (2018), corporate technological innovation can be divided into two forms: exploratory and exploitative innovations. Exploratory innovation is a brand-new model relying on new market exploration and new product development, which is a subversion of the existing knowledge and product forms, aiming at creating brand new products and knowledge forms. Exploitative innovation is a relatively conservative form of innovation, which develops new products and processes based on existing knowledge, technology, and resources, reduces relevant operating costs, improves efficiency, and provides better services to customers. To test the mediating effects of various forms of innovation, models (4)-(5) and models (6)-(7) are established.

$$
\begin{aligned}
& \text { inn }_{i t}=\alpha_{0}+\alpha_{1} \text { ofdi }_{i t}+\alpha_{2} \text { size }_{i t}+\alpha_{3} a_{\text {age }}+\alpha_{i t} \operatorname{lev}_{i t}+\alpha_{5} \text { roa }_{i t} \\
& +\alpha_{6} \text { growth }_{i t}+\alpha_{7} \text { export }_{i t}+\sum \text { year }+\sum s t k c d+\varepsilon_{2 i t} \\
& t f p_{i t}=c_{0}+c_{1} \text { ofdi }_{i t}+c_{2} \text { inn }_{i t}+c_{3} \text { size }_{i t}+c_{4} \text { age }_{i t}+c_{5} \operatorname{lev}_{i t}+c_{6} \text { roa }_{i t} \\
& +c_{7} \text { growth }_{i t}+c_{8} \text { export }_{i t}+\sum \text { year }+\sum s t k c d+\varepsilon_{3 i t} \\
& \text { eri }_{i t}=\alpha_{0}+\alpha_{1} \text { ofdi } i_{i t}+\alpha_{2} \text { size }_{i t}+\alpha_{3} \text { age }_{i t}+\alpha_{4} \text { lev }_{i t}+\alpha_{5} \text { roa }_{i t} \\
& +\alpha_{6} \text { growth }_{i t}+\alpha_{7} \text { export }_{i t}+\sum \text { year }+\sum s t k c d+\varepsilon_{4 i t} \\
& t f p_{i t}=c_{0}+c_{1} \text { ofdi } i_{i t}+c_{2} \text { eri }_{i t}+c_{3} \text { size }_{i t}+c_{4} \text { age }_{i t}+c_{5} \operatorname{lev}_{i t}+c_{6} \text { roa }_{i t} \\
& +c_{7} \text { growth }_{i t}+c_{8} \text { export }_{i t}+\sum \text { year }+\sum s t k c d+\varepsilon_{5 i t} \\
& e t i_{i t}=\alpha_{0}+\alpha_{1} \text { ofdi }_{i t}+\alpha_{2} \text { size }_{i t}+\alpha_{3} a_{g e}+\alpha_{4} \text { lev }_{i t}+\alpha_{5} \text { roa }_{i t} \\
& +\alpha_{6} \text { growth }_{i t}+\alpha_{7} \text { export }_{i t}+\sum \text { year }+\sum s t k c d+\varepsilon_{6 i t} \\
& t f p_{i t}=c_{0}+c_{1} \text { ofdi } i_{i t}+c_{2} e t i_{i t}+c_{3} \text { size }_{i t}+c_{4} \text { age }_{i t}+c_{5} \text { lev }_{i t}+c_{6} \text { roa }_{i t} \\
& +c_{7} \text { growth }_{i t}+c_{8} \text { export }_{i t}+\sum \text { year }+\sum s t k c d+\varepsilon_{7 i t}
\end{aligned}
$$

In the above models, inn denotes technological innovation, eri exploratory innovation and eti exploitative innovation. Model (2), (4), and (6) test the impact of OFDI on technological innovation, exploratory innovation, and exploitative innovation respectively, where $\alpha_{1}$ is the effect coefficients. $c_{1}$ in models (3), (5) and (7) represent the direct effects of technological innovation, exploratory innovation and exploitative innovation on productivity respectively, and $c_{2}$ are the effects of technological innovation and its modalities on enterprise productivity after the effect of OFDI is controlled. Of our concern is the product of the coefficients $\alpha_{1}$ and $c_{2}$ in the set of equations, which portrays the mediating effect of technological innovation and its mod- 
alities. Given the possible endogeneity and sample selection bias, the PSMDID approach is still adopted in the testing of this section.

\section{Baseline Regression Test}

Table 6 empirically tests models (1) to (7) at 1:1 and 1:2 matching ratios respectively, which analyzes the mediating role of technological innovation and its modalities. The regression results show that for technological innovation as mediator (inn), the coefficients $\beta_{1}, \alpha_{1}, c_{1}, c_{2}$ are all significant, indicating that the mediating effect of technological innovation holds and plays a partial mediating role, and hypothesis $\mathrm{H}_{2}$ is confirmed.

Among the technological innovation modalities, the mediating effect of exploratory innovation (eri) exists and it plays a part of mediating role. This may be due to the fact that OFDI strengthens international exchange and cooperation and establishes a natural link between the parent company and its overseas subsidiaries and overseas talents. Overseas subsidiaries can enhance the enterprises' exploratory innovation capabilities by attracting highly qualified talent and

Table 6. Mechanisms of OFDI for high-quality enterprise development: a technological innovation perspective.

\begin{tabular}{|c|c|c|c|c|c|c|}
\hline \multirow{2}{*}{ Matching ratio } & \multicolumn{3}{|c|}{$1: 1$} & \multicolumn{3}{|c|}{$1: 2$} \\
\hline & inn & eri & eti & inn & eri & eti \\
\hline \multirow{2}{*}{$\beta_{1}$} & $0.169^{* * *}$ & $0.169^{* * *}$ & $0.169^{* * *}$ & $0.165^{\star * *}$ & $0.165^{\star * *}$ & $0.165^{\star * *}$ \\
\hline & $(5.77)$ & $(5.77)$ & $(5.77)$ & $(6.49)$ & $(6.49)$ & $(6.49)$ \\
\hline \multirow{2}{*}{$\alpha_{1}$} & $0.227^{\star * *}$ & $0.552^{* * *}$ & $0.753^{\star}$ & $0.202^{\star * *}$ & $0.373^{\star *}$ & $0.773^{\star *}$ \\
\hline & $(4.05)$ & $(2.74)$ & $(1.91)$ & $(4.43)$ & $(2.38)$ & $(2.23)$ \\
\hline \multirow{2}{*}{$C_{1}$} & $0.126^{\star * *}$ & $0.167^{\star * *}$ & $0.167^{\star * *}$ & $0.126^{\star * *}$ & $0.164^{\star * \star}$ & $0.163^{\star * *}$ \\
\hline & $(4.70)$ & $(5.72)$ & $(5.72)$ & $(5.53)$ & $(6.46)$ & $(6.45)$ \\
\hline \multirow{2}{*}{$C_{2}$} & $0.190^{\star * *}$ & $0.003^{\star *}$ & $0.002^{*}$ & $0.194^{\star * *}$ & $0.003^{\star *}$ & $0.003^{\star * *}$ \\
\hline & $(9.03)$ & $(2.23)$ & $(1.94)$ & $(11.26)$ & $(2.53)$ & $(2.78)$ \\
\hline Year & Yes & Yes & Yes & Yes & Yes & Yes \\
\hline Industry & Yes & Yes & Yes & Yes & Yes & Yes \\
\hline Sobel & 6.12 & 1.76 & 1.77 & 7.11 & 1.79 & 2.43 \\
\hline $\begin{array}{c}\text { Goodman-1 } \\
\text { (Aroian) }\end{array}$ & 6.11 & 1.70 & 1.71 & 7.11 & 1.73 & 2.38 \\
\hline Goodman-2 & 6.12 & 1.84 & 1.85 & 7.12 & 1.86 & 2.48 \\
\hline Mediating Effect & 0.043 & 0.002 & 0.002 & 0.039 & 0.001 & 0.002 \\
\hline $\begin{array}{c}\text { Mediating } \\
\text { effect/total effect }\end{array}$ & $25.52 \%$ & $0.98 \%$ & $0.89 \%$ & $23.75 \%$ & $0.68 \%$ & $1.41 \%$ \\
\hline Observations & 6909 & 6909 & 6909 & 10041 & 10041 & 10041 \\
\hline
\end{tabular}

The standard errors for robust clustering are in parentheses. ${ }^{*},{ }^{* *}$, and ${ }^{* * *}$ indicate significant at the level of $10 \%, 5 \%$, and $1 \%$ respectively. 
sending them to the parent company to help it design and produce "disruptively" innovative products, thereby increasing productivity. For exploitative innovation (eti), according to the test of mediating effect, the coefficients $\beta_{1}, \alpha_{1}, c_{1}, c_{2}$ are all significant at the level of $1 \%$. This suggests that the mediating effect of exploitative innovation also exists, that is to say, exploitative innovation partially mediates between OFDI and productivity, and acts as intermediate support to the impact of multinational investment on productivity. A possible explanation for this is that enterprises conducting OFDI face more intense international competition and have to meet higher international standards, so in order to improve product quality and standards, they have to struggle to improve their original product design and increase their overseas competitiveness, thus increasing productivity. In addition, OFDI also benefits from the convenience brought by high-tech industrial agglomeration, which may prompt companies into R\&D mode quickly and bring new inspirations when enhancing their independent $\mathrm{R} \& \mathrm{D}$ capabilities, so as to help optimize their original products, enhance exploitative innovation capabilities, and effectively improve their productivity. In conclusion, $\mathrm{H}_{3}$ is supported by the fact that OFDI can promote the efficiency of enterprises through both exploratory and exploitative innovation, thus achieving high-quality development.

\section{Robustness Test}

\subsection{Parallel Trend Test of DID Model}

In fact, only quasi-natural experiments need to maintain exogeneity, DID model implicitly assumes that the time trends of the treatment group and control group should be parallel if there are no policy shocks. To effectively rule out the endogeneity problem, this paper tests whether the parallel trend assumption of the DID model exists. Based on Jacobson, Lalonde and Sullivan (1993), this section utilizes an event study to conduct the test. The expression is shown in Equation (3).

$$
t f p_{i t}=\beta_{0}+\sum_{-3}^{7} \delta_{k} d u_{i, t_{0}+k}+\sum \text { year }+\sum s t k c d+\varepsilon_{i t}
$$

In this, $d u$ is the dummy variable for the presence or absence of OFDI, same as above. $t_{0}$ denotes the year when the enterprise starts out OFDI. $k$ donates the year after the enterprise starts out OFDI. $\delta_{k}$ indicates whether there is a significant difference in productivity between the experimental group and the control group at year $k$. Other variables have the same meaning as above.

Figure 2 shows the estimation results of $\delta_{k}$ at $95 \%$ confidence interval. The paper finds that the two years before the start of OFDI, $\delta_{k}$ contains 0 at $95 \%$ confidence interval, meaning not significant. The results indicate that there is no significant difference between the experimental and control group enterprises before starting OFDI, which is consistent with the parallel trend hypothesis. Starting from $k=0$ (i.e., after the enterprises conduct OFDI), $\delta_{k}$ values show a significant upward trend, indicating that the productivity of enterprises in the 


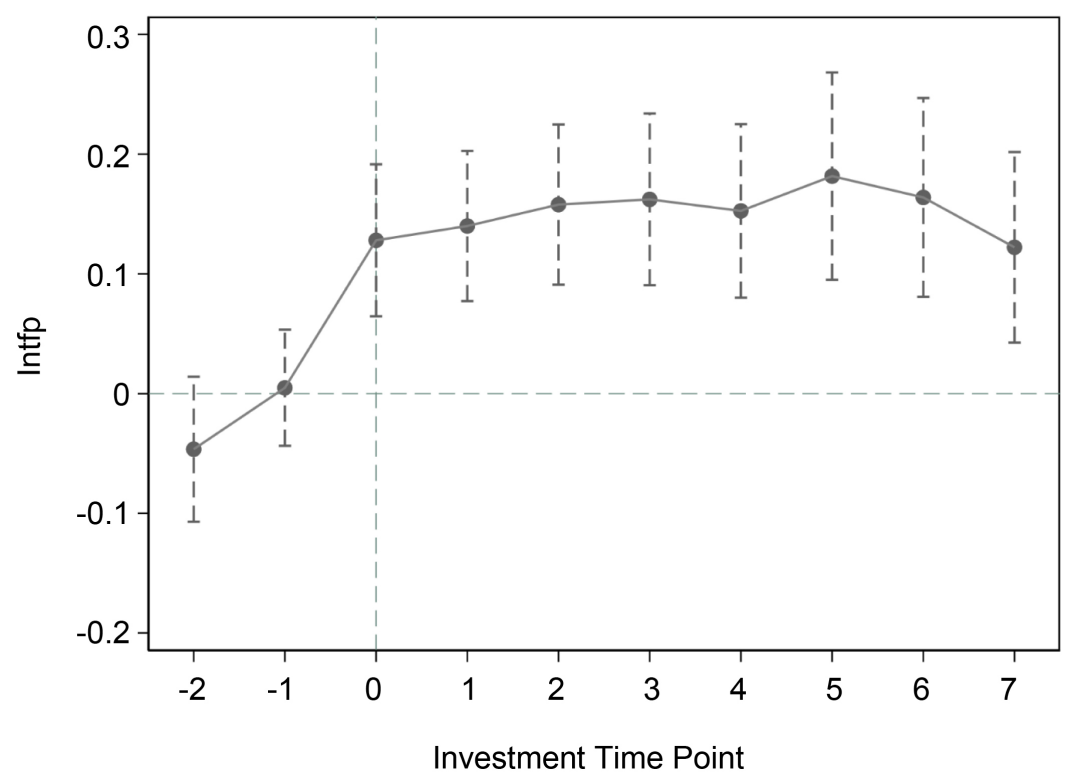

Figure 2. Parallel trend test.

experimental group is significantly higher than that of the control group. Therefore, the results indicate that the multi-temporal DID method used in this paper is consistent with the parallel trend hypothesis test.

\subsection{Placebo Test}

In the quasi-natural experiments in this paper, although we have controlled for a large number of variables characterizing productivity differences in Model (1), it is not possible to control for all enterprise characteristics and there may still be other unobservable enterprise characteristics due to data limitations. In this regard, this paper follows Ferrara, Duryea and Alberto (2011) and adopts the following method to indirectly test whether these missing unobserved enterprise characteristics may have an impact on the estimation results. First, we derive ofdi $_{i t}$, based on Model (1), an expression for the estimate of coefficient $\hat{\beta}$ as follow:

$$
\hat{\beta}=\beta+\gamma \frac{\operatorname{cov}\left(\text { ofdi }_{i t}, \varepsilon_{1 i t} \mid \text { size }_{i t}, \text { age }_{i t}, \text { lev }_{i t}, \text { roa }_{i t}, \text { growth }_{i t}, \text { export }_{i t}\right)}{\operatorname{var}\left(\text { ofdi }_{i t} \mid \text { size }_{i t}, \text { age }_{i t}, \text {,ev }_{i t}, \text { roa }_{i t}, \text { growth }_{i t}, \text { export }_{i t}\right)}
$$

All variables in this equation are defined as described in the previous section. If $\gamma=0$, the unobserved factor does not affect the estimate, and $\hat{\beta}$ is unbiased. But this cannot directly test $\gamma$ is zero or not. If a certain variable can be found to replace $o f d i_{i t}$ and theoretically this variable does not affect corresponding $t f p_{i t}$ (meaning $\beta=0$ ). Then after $\hat{\beta}=0$ is estimated, we can prove $\gamma=0$. To this end, we make the OFDI shock to productivity random (computer-generated) and repeat the random process 500 times, so that the randomization ensures that there is no effect on $t f p_{i t}$, that is $\beta^{\text {random }}=0$. In this case, mean of $\hat{\beta}^{\text {random }}$ can be estimated and the distribution of the $500 \hat{\beta}^{\text {random }}$ estimated is shown in Figure 3 . It can be found that through randomization, $\hat{\beta}^{\text {random }}$ concentrates around 


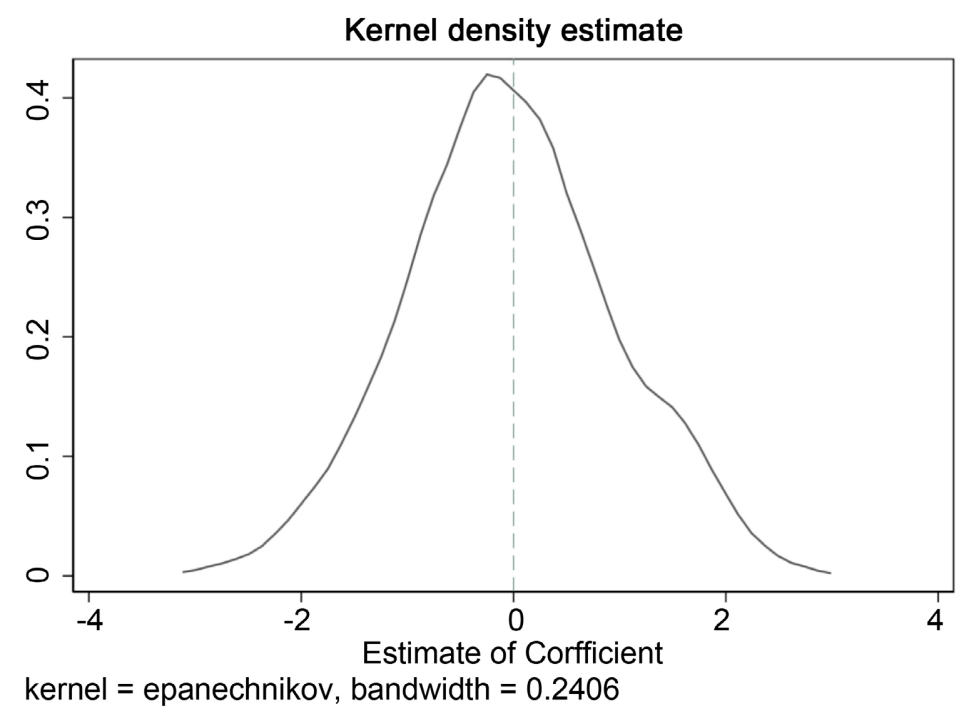

Figure 3. Distribution of $\hat{\beta}^{\text {random }}$ after randomization (placebo test).

0 , which in turn infers that $\gamma=0$, supporting the idea that the unobserved enterprise characteristics have little effect on the estimation results and that the results of the benchmark test in the previous part are robust.

\subsection{Replacement of Calculation Method of the Dependent Variable}

Given that the results obtained by the single explained variable measurement method may be accidental and erroneous, this paper replaces the calculation method of total factor productivity with the OP method to conduct a robustness test for the productivity of listed companies. The results are shown in Table 7. Column (1) shows the results of the benchmark regression of the overall sample with a 1:1 matching ratio. The coefficient of the variable ofd $i$ is significantly positive at the statistical level of $1 \%$, which supports $\mathrm{H}_{1}$ : There is a significant impact of OFDI on productivity. The regression results also follow the same trend as those using the LP method in terms of equity heterogeneity, regional heterogeneity, and policy heterogeneity, showing strong robustness.

\subsection{Replacement of Measurement Method of Mediating Variables}

In this paper, $R \& D$ investment is used in the main regression to distinguish technological innovation and its modalities, and this section uses patent applications for robustness testing. Specifically, this paper uses a synthesis of three types of patent applications-invention, utility model patents, and design patents-to denote technological innovation (inn). Based on Arndt and Sternberg (2000), the inventions of enterprises are used to indicate exploratory innovation (eri), and the sum of utility model patents and design patents measures exploitative innovation (eti). The results are shown in Table 8 . This section tests the three matching ratios respectively, and all of them support $\mathrm{H}_{2}$ and $\mathrm{H}_{3}$, the conclusions being robust. 
Figure 7. Regression results based on OP method.

\begin{tabular}{|c|c|c|c|c|c|c|c|c|c|c|c|c|}
\hline & $\begin{array}{l}\text { Overall } \\
\text { sample }\end{array}$ & State-owned & Private & East & Middle & West & $\begin{array}{l}\text { Policy } \\
\text { support }\end{array}$ & $\begin{array}{l}\text { Non-central } \\
\text { government } \\
\text { policy } \\
\text { support }\end{array}$ & $\begin{array}{c}\text { Central } \\
\text { government } \\
\text { policy } \\
\text { support \& } \\
\text { manufacturing }\end{array}$ & $\begin{array}{c}\text { Central } \\
\text { government } \\
\text { policy } \\
\text { support \& } \\
\text { service } \\
\text { industry }\end{array}$ & $\begin{array}{c}\text { Non-policy } \\
\text { support \& } \\
\text { manufacturing }\end{array}$ & $\begin{array}{c}\text { Non-central } \\
\text { government } \\
\text { policy } \\
\text { support \& } \\
\text { service } \\
\text { industry }\end{array}$ \\
\hline & (1) & (2) & (3) & (4) & (5) & (6) & (7) & (8) & (9) & (10) & (11) & (12) \\
\hline & tfp_op & tfp_op & tfp_op & tfp_op & tfp_op & tfp_op & tfp_op & tfp_op & tfp_op & tfp_op & tfp_op & tfp_op \\
\hline \multirow[t]{2}{*}{ ofdi } & $0.092^{* * *}$ & $0.080^{* * *}$ & $0.052^{* * *}$ & $0.083^{* *}$ & $0.093^{\star}$ & $0.144^{* *}$ & $0.080^{* * *}$ & $0.073^{\star *}$ & $0.058^{* * *}$ & $0.129^{* * *}$ & 0.047 & $0.142^{\star}$ \\
\hline & $(6.22)$ & (3.39) & (2.62) & $(2.50)$ & (1.69) & $(2.37)$ & $(4.72)$ & $(2.56)$ & (3.16) & (2.67) & $(1.60)$ & (1.78) \\
\hline \multirow[t]{2}{*}{ size } & $-0.061^{* * *}$ & -0.016 & $-0.069^{* * *}$ & $-0.074^{* * *}$ & $-0.097^{\star *}$ & -0.020 & $-0.076^{* * *}$ & 0.003 & $-0.048^{* * *}$ & $-0.125^{* * *}$ & 0.005 & -0.042 \\
\hline & $(-7.89)$ & $(-1.12)$ & $(-7.07)$ & $(-3.73)$ & $(-2.33)$ & $(-0.46)$ & $(-8.67)$ & $(0.16)$ & $(-4.57)$ & $(-6.15)$ & $(0.25)$ & $(-0.90)$ \\
\hline \multirow[t]{2}{*}{ age } & $0.058^{* *}$ & 0.048 & -0.035 & 0.055 & 0.130 & $0.181^{*}$ & $0.082^{* * *}$ & -0.004 & 0.052 & 0.122 & 0.040 & -0.217 \\
\hline & $(2.20)$ & $(0.89)$ & $(-0.92)$ & $(0.95)$ & $(1.37)$ & (1.67) & (2.74) & $(-0.07)$ & $(1.60)$ & (1.33) & $(0.71)$ & $(-1.25)$ \\
\hline \multirow[t]{2}{*}{ lev } & $0.577^{* * *}$ & $0.588^{* * *}$ & $0.557^{* * *}$ & $0.566^{* * *}$ & $0.481^{* * *}$ & $0.561^{* * *}$ & $0.584^{* * *}$ & $0.411^{* * *}$ & $0.586^{* * *}$ & $0.612^{\star * *}$ & $0.330^{* * *}$ & $1.244^{* * *}$ \\
\hline & (14.07) & $(8.05)$ & (10.64) & (5.28) & (2.78) & $(2.81)$ & (12.21) & $(4.71)$ & (11.35) & $(4.07)$ & $(3.71)$ & $(4.57)$ \\
\hline \multirow[t]{2}{*}{ roa } & $0.393^{* * *}$ & $0.282^{* * *}$ & $0.516^{* * *}$ & $0.456^{* * *}$ & $0.234^{* *}$ & $0.443^{* * *}$ & $0.467^{* * *}$ & $0.592^{* * *}$ & $0.595^{* * *}$ & $0.201^{* * *}$ & $0.463^{* * *}$ & $0.628^{* * *}$ \\
\hline & (15.72) & $(8.17)$ & (13.85) & $(4.52)$ & $(2.21)$ & (3.33) & (14.34) & $(9.83)$ & (15.04) & (3.11) & $(7.56)$ & $(3.26)$ \\
\hline \multirow[t]{2}{*}{ growth } & $0.014^{* * *}$ & $0.015^{* * *}$ & $0.013^{* * *}$ & 0.014 & 0.007 & $0.016^{* *}$ & $0.032^{* * *}$ & 0.002 & $0.027^{* * *}$ & $0.094^{* * *}$ & -0.001 & 0.012 \\
\hline & $(6.76)$ & $(3.01)$ & (5.85) & $(1.31)$ & $(0.83)$ & $(2.20)$ & $(9.96)$ & $(0.74)$ & (8.69) & (3.40) & $(-0.16)$ & (1.38) \\
\hline \multirow[t]{2}{*}{ export } & 0.001 & -0.002 & $0.006^{* * *}$ & 0.002 & 0.003 & -0.004 & 0.002 & -0.000 & $0.004^{* *}$ & -0.005 & -0.001 & 0.007 \\
\hline & $(0.71)$ & $(-0.77)$ & (2.66) & $(0.74)$ & $(0.77)$ & $(-0.67)$ & $(0.90)$ & $(-0.06)$ & $(2.12)$ & $(-0.97)$ & $(-0.24)$ & $(0.94)$ \\
\hline \multirow[t]{2}{*}{ Constant term } & $4.415^{* * *}$ & $3.621^{* * *}$ & $4.556^{* * *}$ & $4.636^{* * *}$ & $5.152^{* * *}$ & $3.355^{* * *}$ & $4.655^{* * *}$ & $3.457^{* * *}$ & $4.117^{* * *}$ & $5.325^{* * *}$ & $3.412^{* * *}$ & $4.265^{* * *}$ \\
\hline & $(29.05)$ & $(11.93)$ & (24.16) & (12.70) & $(6.50)$ & $(4.17)$ & (27.17) & $(8.98)$ & (20.32) & (11.70) & (8.13) & $(4.65)$ \\
\hline Year & Yes & Yes & Yes & Yes & Yes & Yes & Yes & Yes & Yes & Yes & Yes & Yes \\
\hline Enterprise & Yes & Yes & Yes & Yes & Yes & Yes & Yes & Yes & Yes & Yes & Yes & Yes \\
\hline Observations & 7578 & 2450 & 4509 & 5147 & 1137 & 959 & 5319 & 2259 & 4188 & 761 & 1505 & 533 \\
\hline$R^{2}$ & 0.119 & 0.133 & 0.135 & 0.113 & 0.139 & 0.187 & 0.159 & 0.123 & 0.180 & 0.188 & 0.173 & 0.128 \\
\hline $\mathrm{F}$ & 41.220 & 15.494 & 26.869 & 7.917 & 4.280 & 5.878 & 39.412 & 11.310 & 36.308 & 6.077 & 11.501 & 2.445 \\
\hline
\end{tabular}

The standard errors for robust clustering are in parentheses. This paper also tests the data at 1:2, 1:3, and 1:5 matching ratios, showing stable results, which are not presented due to space limitations.

\section{Conclusion}

When China is making every effort to promote high-quality economic development and build a new development pattern that is dominated by domestic circulation and promoted by domestic and international circulation, an in-depth study on how "going global" strategy provides technological promotion and efficiency gain for enterprises is not only conducive to enhancing their competitiveness through the international markets but also can promote benign interaction between domestic and international markets and provide a strong boost for enterprises to grow stronger. Based on the data of A-share listed companies in 
Table 8. Regression results of mediating effect of patents.

\begin{tabular}{|c|c|c|c|c|c|c|c|c|c|}
\hline \multirow{2}{*}{ Matching ratio } & \multicolumn{3}{|c|}{$1: 1$} & \multicolumn{3}{|c|}{$1: 2$} & \multicolumn{3}{|c|}{$1: 3$} \\
\hline & inn & eri & eti & inn & eri & eti & inn & eri & eti \\
\hline \multirow[t]{2}{*}{$\beta_{1}$} & $0.165^{\star \star \star}$ & $0.165^{\star * *}$ & $0.165^{\star * *}$ & $0.176^{\star * *}$ & $0.176^{\star * *}$ & $0.176^{* * *}$ & $0.184^{\star * *}$ & $0.184^{\star * \star}$ & $0.184^{* * *}$ \\
\hline & $(6.73)$ & $(6.73)$ & $(6.73)$ & $(7.54)$ & $(7.54)$ & $(7.54)$ & $(7.91)$ & $(7.91)$ & $(7.91)$ \\
\hline \multirow[t]{2}{*}{$\alpha_{1}$} & $0.363^{\star * *}$ & $0.193^{\star * *}$ & $0.170^{\star * *}$ & $0.293^{\star * *}$ & $0.149^{* * *}$ & $0.143^{* * *}$ & $0.274^{\star * *}$ & $0.140^{* * *}$ & $0.134^{\star * *}$ \\
\hline & $(3.99)$ & $(4.02)$ & $(3.23)$ & (3.53) & $(3.45)$ & $(2.98)$ & $(3.37)$ & $(3.31)$ & $(2.86)$ \\
\hline \multirow[t]{2}{*}{$C_{1}$} & $0.156^{\star * *}$ & $0.157^{\star * *}$ & $0.159^{* * *}$ & $0.169^{\star * *}$ & $0.170^{\star * *}$ & $0.171^{\star * *}$ & $0.178^{\star * *}$ & $0.179^{\star * *}$ & $0.180^{* * *}$ \\
\hline & $(6.40)$ & $(6.45)$ & $(6.53)$ & $(7.29)$ & $(7.35)$ & $(7.37)$ & $(7.68)$ & $(7.73)$ & $(7.76)$ \\
\hline \multirow[t]{2}{*}{$c_{2}$} & $0.025^{\star * *}$ & $0.043^{\star * *}$ & $0.033^{\star * *}$ & $0.025^{\star \star \star}$ & $0.039^{\star * *}$ & $0.035^{\star * *}$ & $0.023^{* * *}$ & $0.036^{\star * *}$ & $0.032^{* * *}$ \\
\hline & $(5.71)$ & $(5.58)$ & $(4.90)$ & $(6.44)$ & $(5.93)$ & $(5.98)$ & $(5.98)$ & $(5.62)$ & $(5.58)$ \\
\hline Year & Yes & Yes & Yes & Yes & Yes & Yes & Yes & Yes & Yes \\
\hline Enterprise & Yes & Yes & Yes & Yes & Yes & Yes & Yes & Yes & Yes \\
\hline Sobel & 4.69 & 4.47 & 3.66 & 4.89 & 4.45 & 3.99 & 4.91 & 4.50 & 3.98 \\
\hline $\begin{array}{l}\text { Goodman-1 } \\
\text { (Aroian) }\end{array}$ & 4.67 & 4.45 & 3.63 & 4.87 & 4.43 & 3.97 & 4.90 & 4.48 & 3.96 \\
\hline Goodman-2 & 4.72 & 4.50 & 3.69 & 4.90 & 4.47 & 4.01 & 4.93 & 4.52 & 4.00 \\
\hline Mediating Effect & 0.009 & 0.008 & 0.006 & 0.007 & 0.006 & 0.005 & 0.006 & 0.005 & 0.004 \\
\hline $\begin{array}{c}\text { Mediating } \\
\text { effect/total effect }\end{array}$ & $5.50 \%$ & $5.03 \%$ & $3.40 \%$ & $4.16 \%$ & $3.30 \%$ & $2.84 \%$ & $3.43 \%$ & $2.74 \%$ & $2.33 \%$ \\
\hline Observations & 9566 & 9566 & 9566 & 13,825 & 13,825 & 13,825 & 15,996 & 15,996 & 15,996 \\
\hline
\end{tabular}

The standard errors for robust clustering are in parentheses. ${ }^{\star},{ }^{\star *}$, and ${ }^{\star \star \star}$ indicate significant at the level of $10 \%, 5 \%$, and $1 \%$ respectively. 
Based on the research in this paper, the following implications can be made:

First, in the new economic development pattern, China should further promote the "going global" and "dual-circulation" strategy to promote high-quality opening-up. The government should focus on creating a favorable policy environment, expanding the coverage and strength of central government policy support, and providing a fair competition platform and opportunities for enterprises of all types. In addition, the government can also provide effective tax support and policy guidance for overseas expansion to motivate enterprises to "go global". And through differentiated taxation methods, the government can guide enterprises' technological innovation, improve the innovation efficiency of enterprises, especially that of state-owned enterprises and enterprises in the western region, and strengthen the role of technological innovation as a mediator to promote the high-quality development of OFDI enterprises to fully serve the new pattern of dual-circulation economic development.

Second, enterprises can reasonably choose innovation methods according to their own development stages to help their high-quality development. Since exploitative innovation can effectively promote the high-quality development of OFDI enterprises, enterprises that have just started overseas investment can achieve productivity improvement and high-quality development partly through exploitative innovation with lower fixed input. Because of the more obvious effect of exploratory innovation on promoting high-quality development of enterprises, relatively matured enterprises should increase investment in exploratory innovation, strengthen technology learning and technology absorption in host countries, enhance independent innovation, increase the strength of disruptive innovation, and provide all-round support for the solution of core and key technologies, so as to enhance the level of high-quality development of enterprises.

This paper constructs a framework of the impact of OFDI on firm productivity from micro-level OFDI behavior and insights into its role by introducing heterogeneous innovation, which has theoretical and practical significance. At the same time, there are limitations in this paper, which provide research insights for future studies: 1) The period of the empirical evidence in this paper is 2008-2019. The outbreak of Corona Virus Disease 2019 in December 2019 had an immediate impact on outbound direct investment by Chinese companies, so 2020 was not included in the scope of the study. Nevertheless, international financial and economic markets were subject to frequent changes during the sample period, such as the trade war and the European debt crisis. Given the availability and quantifiability of data, this paper does not exclude the impact of policy changes on the economic consequences of OFDI during the sample period, and future studies can take policy changes and other factors into account. 2) There are differences in investment incentives and risks across firms' OFDI, which may infect enterprise productivity. On the one hand, to ensure the accuracy of PSM matching, the 1:1 matching ratio used in this paper would result in a large loss of 
sample; on the other hand, there are lots of missing variables for the measurement of heterogeneous innovation. Therefore, to ensure sufficient observations and adequate feasibility, this paper only starts from the overall investment behavior, without refining the investment motives and investment risks of individual enterprises' OFDI. Future studies can consider starting from the heterogeneity of OFDI.

\section{Acknowledgements}

This work was supported by the National Natural Science Foundation of China under Grant number 71232004; Social Science Planning Project of Chongqing under Grant number 2018YBJJ032 \& 2021NDYB079; and Graduate Innovation Project of Chongqing under Grant number CYS20322.

\section{Conflicts of Interest}

The authors declare no conflicts of interest regarding the publication of this paper.

\section{References}

Aitken, B., \& Harrison, A. (1994). Do Domestic Firms Benefit from Foreign Direct Investment? Evidence from Panel Data. Policy Research Working Paper, 28, 6-16.

Arndt, O., \& Sternberg, R. (2000). Do Manufacturing Firms Profit from Intraregional Innovation Linkages? An Empirical Based Answer. European Planning Studies, 8, 465485. https://doi.org/10.1080/713666423

Beck, T., Levine, R., \& Levkov, A. (2010). Big Bad Banks? The Winners and Losers from Bank Deregulation in the United States. The Journal of Finance, 65, 1637-1667. https://doi.org/10.1111/j.1540-6261.2010.01589.x

Benjamin, B., René, S., \& Wang, Z. X. (2020). Does the Stock Market Make Firms More Productive? Journal of Financial Economics, 136, 281-306. https://doi.org/10.1016/j.jfineco.2019.09.006

Bernard, A. B., Jensen, J. B., \& Schott, P. K. (2006). Trade Costs, Firms and Productivity. Journal of Monetary Economics, 53, 917-937. https://doi.org/10.1016/j.jmoneco.2006.05.001

Bi, X. F., Zhai, S. P., \& Jiang, B. Q. (2017). Government Subsidies, Financial Slack and Ambidextrous Innovation. Accounting Research, 1, 46-52, 95.

Bronzini, R., \& Piselli, P. (2009). Determinants of Long-Run Regional Productivity: The Role of R\&D, Human Capital and Public Infrastructure. Regional Science \& Urban Economics, 39, 187-199. https://doi.org/10.1016/j.regsciurbeco.2008.07.002

Bruno, A., Ivan, L., \& Stéphane, R. (2016). Product Market Regulation, Innovation, and Productivity. Research Policy, 45, 2087-2104.

https://doi.org/10.1016/j.respol.2016.08.003

Cheng, Y. (2011). An Empirical Study on China's ODI Reverse Technology Spillover: An Absorptive Capacity Perspective. China Soft Science, No. 10, 61-72.

Ferrara, E. L., Duryea, S., \& Alberto, C. (2011). Soap Operas and Fertility: Evidence from Brazil. IDB Publications.

Gan, J. X., \& Qi, Y. (2018). The Path of Ambidextrous Innovation, Knowledge Field and Intellectual Property Capacity. China Soft Science, 36, 2078-2091. 
Guo, T., \& Sun, Y. Y. (2021). The Riddle of the Coexistence of Environmental Regulation and High-Quality Development of Enterprises-From the Perspective of Heterogeneous Enterprises and Total Factor Productivity Decomposition. Jinan Journal (Philosophy \& Social Sciences), 43, 102-118.

Hang, H., \& Zhao, G. H. (2018). The Mechanism and Empirical Study on the Influence of Foreign Direct Investment to China's Innovation Capability. Science \& Technology Progress and Policy, 35, 32-37.

Jacobson, L. S., Lalonde, R. J., \& Sullivan, D. G. (1993). Earnings Losses of Displaced Workers. American Economic Review, 83, 685-709.

Javorcik, B. S. (2004). Does Foreign Direct Investment Increase the Productivity of Domestic Firms? In Search of Spillovers through Backward Linkages. American Economic Review, 94, 605-627. https://doi.org/10.17848/wp92-11

Jiang, G. H., \& Jiang, D. C. (2014). Outward Foreign Direct Investment by Chinese Industrial Firms and Corporate Productivity Progress. World Economy, 37, 53-76.

Levinsohn, J., \& Petrin, A. (2003). Estimating Production Functions Using Inputs to Control for Unobservable. The Review of Economic Studies, 70, 317-341.

Li, B. X., Pang, B., \& Zhang, L. (2019). Examination of Reversed Innovation Efficiency Promotion Driven by OFDI in China-Based on the Perspective of IPR Regulation. Economic and Management Research, 40, 58-70. https://doi.org/10.13502/j.cnki.issn1000-7636.2019.03.005

Liu, X. M., Wang, J., \& Lu, J. (2016). China's OFDI and the Breakthrough of OFDI Theory: A Literature Review and Research. Journal of Zhongnan University of Economics and Law, 2, 86-95, 160.

Luo, C. Y., \& Zhang, Z. X. (2020). The Complementarity between Export and R\&D and Its Impact on Productivity: Evidence from List Companies in China. Quantitative Economic and Technical Economics Research, 37, 134-154. https://doi.org/10.13653/j.cnki.jqte.2020.07.007

Mao, Q. L., \& Xu, J. Y. (2014). Does OFDI by Chinese Companies Promote Corporate Innovation? World Economy, 37, 98-125.

Ming, X. N., Yan, H. R., \& Xian, G. M. (2019). Outward Foreign Direct Investment and Its Effects on Innovation. Southern Economy, No. 8, 39-55. https://doi.org/10.19592/j.cnki.scje.351602

Sheng, M. Q., Wu, S. M., \& Zhang, Y. N. (2020). Exploratory Innovation and Enterprise Total Factor Productivity. Industrial Economics Research, No. 1, 28-41. https://doi.org/10.13269/j.cnki.ier.2020.01.003

Song, Y. G., \& Wu, Y. G. (2016). Institutional Environment, OFDI, and TFP Growth: An Analysis from a Spatial Perspective. World Economic Research, No. 11, 70-85, 136. https://doi.org/10.13516/j.cnki.wes.2016.11.008

Wang, G. J., \& Zhang, H. (2020). The Belt and Road Initiative and the TFP of China's OFDI Enterprises: A Perspective on Investing in Developed Countries. World Econo$m y, 43,49-72$.

Wang, H. D., Yue, H., \& Zhang, X. (2019). Research on the Relationship between Corporate Governance Structure and Corporate Performance-A Perspective based on Corporate Total Factor Productivity. Shanghai Economic Research, No. 4, 17-27. https://doi.org/10.19626/j.cnki.cn31-1163/f.2019.04.003

Wang, Y., \& Zhang, Y. H. (2018). The Impact of Collaboration between Internal Governance and External Financing on Enterprises' Productivity. Industrial Economics Research, 9, 101-111. https://doi.org/10.14007/j.cnki.cjpl.2018.05.008 
Weng, Z. L., Zhang, L., Hou, J. T., \& Liu, H. Y. (2004). Testing and Application of the Mediating Effects. Psychology Journal, 5, 614-620.

Wu, M. Q., \& Tong, B. R. (2016). Industrial Agglomeration and Total Factor Productivity of Enterprise: Evidence from Chinese Manufacturing. Industrial Economics Review, 7, 30-44. https://doi.org/10.14007/j.cnki.cjpl.2016.04.003

Xian, G. M., \& Ming, X. N. (2018). Cross Broad Merger and Innovation of Acquiring Firms. Financial Research, 8, 155-171.

Xiao, H. M., \& Liu, H. H. (2014). Learning Effects of Outward Foreign Direct Investment in China. Journal of Finance and Economics, 40, 42-55. https://doi.org/10.16538/j.cnki.jfe.2014.04.010

Yin, D. D., \& Zhang, J. Q. (2016). Reverse Technology Spillover Effects from China's OFDI: An Empirical Analysis from the Perspective of Absorptive Capacity. Journal of International Trade, No. 1, 109-120. https://doi.org/10.13510/j.cnki.jit.2016.01.010

Zeira, J. (2011). Innovations, Patent Races and Endogenous Growth. Journal of Economic Growth, 16, 135-156.

Zeng, P., Zhu, X., \& Sun, K. L. (2019). Effect of Enterprise Absorptive Capacity on Innovative Performance-A Moderated Mediation Model. Journal of South China University of Technology (Social Science Edition), 21, 46-55.

https://doi.org/10.19366/j.cnki.1009-055X.2019.06.006 